\title{
Aquarium Setup and Maintainence ${ }^{1}$
}

\section{Dr. Ruth Francis-Floyd, DVM; Dr. Allen Riggs, DVM; Dr. Roy Yanong, DVM²}

An aquarium can be defined as a container that holds water and is designed in such a way that living aquatic organisms can be maintained over an extended period of time. Aquariums vary tremendously in size and design. They can be as simple as a betta bowl or as complex as a multi-million gallon commercial exhibit.

When considering an aquarium it is important to contemplate where it will be located, which species will be maintained and what type of budget will be available. In general, larger aquariums are easier to work with than smaller ones. Greater investment is required, however, and a greater allocation of space is also needed. An ideal starter tank is probably a thirty-gallon unit. This will not represent a huge investment, but is large enough to allow some dilution of noxious wastes while the system becomes established. It is also large enough to encourage a novice aquarist's enthusiasm for design and species selection.

\section{Components of an Aquarium}

The main components of a simple home aquarium set up include the tank itself, a stand, a cover, lighting, a heater, an air pump, and filtration.
There are three basic types of filtration, biological, mechanical, and chemical. Every aquarium must have biological and mechanical filtration. Use of chemical filtration will be determined by the interests and the needs of the aquarist.

\section{Biological Filter}

Biological filtration is the oxidation of waste products, specifically ammonia, to nitrite and then nitrate. Most fish foods have high levels of protein and the resultant waste product is ammonia. Fish excrete ammonia passively across the gill membrane. Once ammonia (NH3) is released into the water column an $=\mathrm{m}$ is established between $\mathrm{NH}_{3}$ and $\mathrm{Nh}_{4}+$. Lower ph $(<7)$ favors ammonium $\left(\mathrm{Nh}_{4}+\right)$, which is less toxic to fish; higher $\mathrm{pH}$ favors $\mathrm{NH}_{3}$, which can be highly toxic to fish. Regardless of ionic state, ammonia molecules are oxidized to nitrite $\left(\mathrm{NO}_{2}\right)$ by a group of bacteria generally referred to as nitrosomonas Sp. A second group of nitrifying bacteria, nitrobacteria $\mathrm{Sp}$, oxidizes NO2 to NO3. Nitrate is generally considered less toxic to fish though accumulations in marine tanks may be problematic. Oxidation of nitrogenous wastes is an aerobic process.

1. This document is VM144, one of a series of the Veterinary Medicine-Large Animal Clinical Sciences Department, Florida Cooperative Extension Service, Institute of Food and Agricultural Sciences, University of Florida. Original publication date August 2003. Visit the EDIS Web Site at http://edis.ifas.ufl.edu.

2. Ruth Francis-Floyd, Professor, Department of Large Animal Clinical Sciences (College of Veterinary Medicine) and Department of Fisheries and Aquatic Sciences, Florida Cooperative Extension Service, Institute of Food and Agricultural Sciences, University of Florida, Gainesville, 32611; Allen Riggs, Lecturer, College of Veterinary Medicine, Department of Large Animal Clinical Sciences; Roy Yanong, Assistant Professor, Department of Fisheries and Aquatic Sciences.

The Institute of Food and Agricultural Sciences is an equal opportunity/affirmative action employer authorized to provide research, educational information and other services only to individuals and institutions that function without regard to race, color, sex, age, handicap, or national origin. For information on obtaining other extension publications, contact your county Cooperative Extension Service office. Florida Cooperative Extension Service/Institute of Food and Agricultural Sciences/University of Florida/Christine Taylor Waddill, Dean. 
Nitrate is removed from most small aquariums by water deltas and living plants, if any are present. Large, commercial scale exhibits may provide separate biological filtration for denitrification of $\mathrm{NO} 3$ to $\mathrm{N} 2(\mathrm{~g})$. This is an anaerobic process, and requires use of methane as a carba source for the bacteria. This process is not suitable for use in small, private aquaria given the present state of technology.

\section{Mechanical Filtration}

Mechanical filters are designed to remove particulate matter from the water. These are usually placed in line in front of the biological filter to avoid large particles getting into the biological filter bed. Mechanical filters can be made of many different materials including filter floss, foam, gravel and diatomaceous earth. Sand is not generally recommended because the small particle size can lead to channeling and development of anaerobic areas within the filter bed. Anaerobic areas can be very detrimental because toxins accumulate there, including water. Mechanical filters do require regular maintenance and must be replaced or cleaned regularly to ensure proper function.

\section{Chemical Filtration}

Chemical filtration can be considered optional for many systems. The general role of chemical filtration is to remove colored or odiforous compounds form the water column. There are a number of common materials used to meet this need in home aquaria. Activated carbon may be the most common molecule and is primarily used to enhance water clarification. It will not remove nitrogenous wastes or soften the water. Activated carbon will remove chlorine, chemical treatments, including dye, and heavy metals. Periodic replacement is required.

Ammonia adsorbing clays (ie zeolites) adsorb positively charged ions, including ammonium $\left(\mathrm{NH}_{4}^{+}\right)$. They may also remove $\mathrm{Ca}^{2+}$ and $\mathrm{Mg}^{2+}$. It is necessary to rinse these under running tap water prior to use to avoid clouding the water. These clays do not work in seawater.

\section{lon-Exchange Resins}

There are two types of ion-exchange resins in common use. Cationic exchangers soften water, removing $\mathrm{Ca}^{2+}$ and $\mathrm{Mg}^{2+}$ and exchanging these ions for $\mathrm{Na}^{+}$. It may necessary for the aquarist to add back some $\mathrm{Mg}^{2+}$ using epsom salts, and some $\mathrm{Ca}^{2+}$ using dolomite. A decrease in water hardness may be necessary to facilitate successful reproduction of some species. Oyster shell or coral gravel can be used in water that is poorly buffered $(\mathrm{TA}<50 \mathrm{mg} / \mathrm{L})$ to minimize the risk of a sudden drop in ph following the accumulation of organic acid. The addition of $\mathrm{CaCO}_{3}$ to water results in an increase in water hardness $\left(\mathrm{Ca}^{2+}\right)$ and buffer capacity or total alkalinity $\left(\mathrm{CO}_{3}\right)$.

Peat moss has been used to soften water, usually for purposes of breeding fish. Release of a tannic acid will decrease the ph and may add some color the water.

Many types of filtration equipment are sold for use by the home aquarist. Functions of these products are summarized in table one. Once the aquarist appreciates the basic functions of each it is easier to design a system that blends different types of equipment to meet individual needs.

Once the aquarist has designed the system and collected the appropriate materials the set up is fairly straightforward.

\section{Getting Started}

First the location must be selected and the appropriate space cleared. The aquarium must be clean and there must be sufficient space above and behind it for maintenance activities. Prior to set up the aquarium itself should be washed with mild household soap and thoroughly rinsed. If the aquarium is used, then it may be necessary to remove calcium deposits using a commercial product or mild household acid such as vinegar. If an undergravel filter is to be used it is the first item installed into the empty aquarium. Gravel must be thoroughly washed before being placed into the aquarium. It should be placed on top of the undergravel plate at a depth of two to three inches, unless live plants are to be used in which case a depth of five inches is recommended. 
The aquarium should be filled approximately thirty percent of total volume and then rocks and other furnishings can be added. Plants are added next. These can be planted into the gravel directly or left in pots (with potting soil) and then covered with a thin layer of gravel. The heater should be added next. It should not be plugged in for an hour and then a full twenty-four hours should be allotted to allow the temperature to stabilize. The aquarium should then be filled to the desired depth and air connected prior to adding fish. Water must be dechlorinated, and if chloramines are present, attention paid to ammonia released.

\section{Establishing the Tank}

Once the tank is set up and stabilized, fish can be added. Initially, the stocking rate should be light to allow time (4-6 weeks) for biofiltration to become established. Ideally fish should be quarantined for thirty days prior to adding them to the aquarium. This is especially important after the system has stabilized and the resident population of fish is acclimated.

Water quality especially TAN, NO2 and ph, must be monitored closely until the biofilter is firmly established, which is indicated by a drop in NO2. Once established, an aquatic system can be maintained for many years.

\section{Recommended Reading}

Gratzek, JB, 1992, "Aquariology, The Science of FHM", Tetra Press, Morres Plains, NJ, 330pp.

Delbeck, JC and Sprung, J., 1994, "The Reef Aquarium, Volume I", Ricordia Publishing, Coconut Grove, FL, 544 pp. 
Table 1. Filtration capability on common equipment sold to home aquarists.

\begin{tabular}{|c|c|c|c|}
\hline \multicolumn{4}{|c|}{ General Filtration Capability } \\
\hline Equipment & Biological & Mechanical & Chemical \\
\hline \multicolumn{4}{|c|}{$\begin{array}{l}\text { Box Filter } \\
\text { Use: quarantine, } t x \text {, spawning }\end{array}$} \\
\hline with filter floss & yes & yes & no \\
\hline with activated carbon & no & no & yes \\
\hline \multicolumn{4}{|c|}{$\begin{array}{l}\text { Outside Power Filter } \\
\text { Use: breeding fry, quarantine }\end{array}$} \\
\hline with filter floss or foam & yes & yes & no \\
\hline with activated carbon & no & no & yes \\
\hline$\frac{\text { Foam Filters }}{\text { Use: tx, quarantine }}$ & yes & yes & no \\
\hline $\begin{array}{l}\text { Undergravel Filter } \\
\text { Use: display aquaria }\end{array}$ & yes & yes & no \\
\hline \multicolumn{4}{|c|}{$\begin{array}{l}\text { Cannister Filter } \\
\text { Use: heavily stocked systems } \\
\text { Function varies with media used, can "stack" different media. }\end{array}$} \\
\hline
\end{tabular}

